\title{
Awareness of breast cancer among university female students in Baghdad
}

Background: Breast cancer still a major cause of disability and mortality among women throughout the world. Lack of awareness and early detection programs in developing countries is a main reason for escalating the mortality.

Objectives: to assess level of awareness about breast cancer among university female students in Baghdad focusing on knowledge of breast cancer risk factors, warning symptoms and signs and knowledge about the screening method specially breast self-examination.

Methods: A cross-sectional study conducted over two months from first of march through April 2015 and included (240) female students in nonmedical colleges at Al-Rusafa and Al-Karkh districts who completed a comprehensive self-structured questionnaire covering socio-demographic characteristics and (27) questions covering the knowledge of risk factors; warning symptoms and signs of breast cancer and the breast

\section{ABSTRACT}

self- examination. Participants' responses were analyzed statistically and percent score of knowledge level was calculated.

Results: The mean age of students was $(22.8 \pm 3.4)$ years with range (19-30) years, single (75.8\%), and those with no family history of breast cancer $(85.42 \%)$; the internet was the most common source of students' information (34.7\%).

Conclusion: The overall percent score of all students' knowledge about risk factors, warning symptoms and signs and breast self-examination was poor $(<60 \%)$.

Key words: knowledge/female/college

students/breast cancer.

Corresponding Address to

Abrar A R Ahmed( M.B.Ch.B.), Maral F. Thabit (F.I.C.M.S /FM)

Received at 13/6/2017

Accepted at 4/12/2017

\section{INTRODUCTION}

Breast cancer is the most frequent malignancy of women worldwide. It is the leading cause of female cancer related disability and mortality ${ }^{[1]}$ According to the World Health Organization (WHO) each year over 1.4 million women worldwide are diagnosed with breast cancer as it accounts for $23 \%$ of all newly diagnosed cancers ${ }^{[2]}$ Breast cancer is the commonest malignancy among women in countries within the Eastern Mediterranean Regions $(E M R)^{[3]}$. Within the EMR, according to WHO mortality estimates, cancer is the fourth ranked cause of death; succeeding cardiovascular diseases, infectious/parasitic diseases and injuries

In Iraq, it comprises approximately one third of the registered female cancers. The features that justify increasing efforts for breast cancer control in the EMR include the obvious rise in the incidence rates, the higher frequencies of younger ages and advanced stages at the time of presentation and the likely prevalence of more aggressive tumors resulting in high mortality/incidence ratios ${ }^{[3]}$. These factors lead to low five-year survival rates (10-50\%) from breast cancer in many low- and medium-resource countries (LMC) as compared to more than $85 \%$ 5-year survival in high-income countries ${ }^{[4]}$. So early detection in order to improve breast cancer outcome and survival remains the cornerstone of breast cancer control

The incidence of breast cancer is increasing in the developing world due to increase life expectancy, increase urbanization and adoption of western lifestyles ${ }^{[6]}$. In United States of America USA, breast cancer is the most commonly diagnosed cancer in women and considered the $2^{\text {nd }}$ leading cause after skin cancer and cancer related mortality after lung [7] cancer

Although some risk reduction might be achieved with prevention, these strategies cannot eliminate the majority of breast cancers that develop in low- and middleincome countries where breast cancer is diagnosed in very late stages ${ }^{[6]}$ The implementation of early diagnosis programs based on awareness of risk factors, early symptoms and signs and breast-selfexamination (BSE) that should be done monthly day 7-10 post cycle from age 20 years 
for all life \& same day monthly in postmenopausal women both visual \& tactile exam to prompt referral to diagnosis and treatment $[8,9]$ One of the main objectives of the National Program for Early Detection and Down Staging Breast Cancer in Iraq is promoting general public awareness on the risk factors of breast cancer, symptoms and signs of the disease and the available screening tools Objectives of study: to assess level of awareness about breast cancer among university female students in Baghdad focusing on a knowledge of breast cancer risk factors, warning symptoms and signs and knowledge about the screening method specially breast self-examination.

\section{METHODS}

This is a cross-sectional study, the datacollection period extended from the first of March through April 2015 at four non-medical colleges ( 2 from Al-Rusafa and 2 from AlKarkh) namely (University of Mustansiriya / College of Administration and Economics), (The Iraqi University / College of Education for Women), (Mamon University College Department of History), (Dijlah University College - Department of Law).The sample of this study was chosen from university females (between 20-30 years old) since this is the early reproductive age group that share the age of marriage, menstruation, pregnancy \& its related factors. Furthermore, the National Breast Cancer Research Program starts at this age

The study sample included 240 college female students who accepted to participate in the study after clarifying the purpose behind the study, assuring high confidentiality and willing participants gave verbal consent and they were handed a comprehensive questionnaire to be filled and returned back to the investigator inside the lecture hall,

Female college students with ages 19 years and older from non-medical college specialty regardless of their marital status and also not working in the medical field and who were willing to participate in the study were included in the study,

A self-administered questionnaire was designed from heavy literature search such as breast cancer awareness measure version 2 (cancer research United Kingdom, King's College London 2010 ${ }^{[11]}$ utilized to collect data after modified and translated into Arabic version to fit the nature of the study. This modified translated questionnaire comprises socio-demographic characteristics of participants and 27 questions covering the knowledge regarding risk factors, warning symptoms and signs and about knowledge of breast self-exam in 4 sections.

Data management and analysis were conducted by using Excel sheet and SPSS (Statistical Package for Social Sciences) computerized software for windows version 20 . Descriptive statistics were presented as means and standard deviation SD for continuous variables and as frequencies and percentages for categorical variables. And responses of the students toward the questionnaire items were categorized into three categories (yes, no, I don't know) and represented as frequencies and percentages, these responses scored as for yes $=3$, I don't know $=2$ and no $=1$. The percent score for students' responses in each specific item was calculated according to the following equation:

Total scores for all participants in the item $\times$ 100/maximum possible score for all participants in the same item were total scores for all participants in the item $=[$ (No. of yes $\times$ $3)+($ №. of I don't know $\times 2)+($ №. of no $\times 1)$ ] and maximum possible score for all participants in the same item $=$ [No. of total participants $\times 3$ ], based on Triple Likert Scale ${ }^{[12]}$ and after approximation, the cutoff point of percent of knowledge categorized as student less than 60 considered as poor, $60-69 \%$ as fair while those with $70 \%$ or more were considered as good knowledge.

\section{RESULT}

The total number of sample was 240 students with a mean age of $(22.8 \pm 3.4)$ years, age range between $(19-30)$ years. Highest percentage (75.83) \% of the participants were single, whereas the percent of married status were (22.92) \%, Students with no family history were $(85.42) \%$, where the (14.58) \% had 
positive family history as shown in table 1

Table (1): Socio-demographic characteristics of the sample.

\begin{tabular}{|l|c|c|}
\hline Variables & Number & $(\%)$ \\
\hline Age/years & & \\
(mean \pm SD) & $22.8 \pm 3.4$ & \\
\hline Marital status & & \\
- Single & 182 & 75.83 \\
$-\quad$ Married & 55 & 22.92 \\
$-\quad$ Divorced & 3 & 1.25 \\
\hline Family history of & & \\
breast cancer & & \\
$-\quad$ Yes & 35 & 14. \\
\hline No & 205 & 85. \\
\hline
\end{tabular}

Internet was the most common source of students' information $82(34.17 \%)$ then mothers/relatives and friends which represent $45(18.75 \%)$.as shown in table 2 :

Table (2): Sources of information regarding breast cancer( $(\mathrm{N}=\mathbf{2 4 0})$

\begin{tabular}{|l|l|l|}
\hline Internet & $\mathbf{8 2}$ & $\mathbf{3 4 . 1 7}$ \\
\hline TV and Radio & 37 & $\mathbf{1 5 . 4 2}$ \\
\hline Health care providers & $\mathbf{2 0}$ & $\mathbf{8 . 3 3}$ \\
\hline $\begin{array}{c}\text { Health care } \\
\text { providers/mother,friends and } \\
\text { relatives./TV and Radio }\end{array}$ & 15 & 6.25 \\
\hline TV and Radio+Internet & 13 & $\mathbf{5 . 4 2}$ \\
\hline TV and Radio + Mothers/Relatives & $\mathbf{9}$ & $\mathbf{3 . 7 5}$ \\
\hline Others & $\mathbf{2 3}$ & $\mathbf{9 . 5 8}$ \\
\hline
\end{tabular}

Students' knowledge about the risk factors had poor knowledge regarding the percentage of those who answered correctly for each item. The maximum percentage of the risk factor was $(23.33 \%)$ for no breast feeding, whereas the minimum percentage of the risk factor was $(10.00) \%$ which is the alcohol and smoking as presented in table (3). 
Table (3): Frequency Distribution of Students' Responses about Risk Factors of breast cancer.

\begin{tabular}{|c|c|c|c|c|c|c|}
\hline \multirow{2}{*}{ Questions } & \multicolumn{2}{|l|}{ Yes } & \multicolumn{2}{|l|}{ No } & \multicolumn{2}{|c|}{ Don't know } \\
\hline & $\mathbf{N}$ & $\%$ & $\mathbf{N}$ & $\%$ & $\mathbf{N}$ & $\%$ \\
\hline The cancer is hereditary. & 40 & 16.67 & 171 & 71.25 & 29 & 12.08 \\
\hline $\begin{array}{l}\text { It gets more risky with } \\
\text { advancing age. }\end{array}$ & 41 & 17.08 & 163 & 67.92 & 36 & 15.00 \\
\hline $\begin{array}{l}\text { Breast-feeding reduces the } \\
\text { risk of getting it. }\end{array}$ & 56 & 23.33 & 169 & 70.42 & 15 & 6.25 \\
\hline $\begin{array}{l}\text { A painless lump mass in the } \\
\text { breast is a risk factor for } \\
\text { breast cancer. }\end{array}$ & 32 & 13.33 & 180 & 75 & 28 & 11.67 \\
\hline $\begin{array}{l}\text { The } 1^{\text {st }} \text { birth after } 30 \text { years } \\
\text { old increases the risk of it. }\end{array}$ & 43 & 17.92 & 148 & 61.67 & 49 & 20.42 \\
\hline $\begin{array}{l}\text { Nulliparity is a risk factor of } \\
\text { having this cancer. }\end{array}$ & 35 & 14.58 & 178 & 74.17 & 27 & 11.25 \\
\hline $\begin{array}{l}\text { Obesity and no physical } \\
\text { activity increase the risk of having this } \\
\text { cancer. }\end{array}$ & 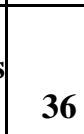 & 15.00 & 184 & 76.67 & 20 & 8.33 \\
\hline $\begin{array}{l}\text { Menarche (below } 11 \text { years old) } \\
\text { and late menopause (above } 55 \text { years } \\
\text { old) increase the risk of } \\
\text { having this cancer. }\end{array}$ & 45 & 18.75 & 180 & 75.00 & 15 & 6.25 \\
\hline $\begin{array}{l}\text { Taking contraceptive pills } \\
\text { and hormone replacement therapy } \\
\text { increase the risk of having this cancer. }\end{array}$ & 29 & 12.09 & 203 & 84.58 & 8 & 3.33 \\
\hline $\begin{array}{l}\text { Exposure to trauma in the } \\
\text { breast increases the breast } \\
\text { cancer risk. }\end{array}$ & 25 & 10.42 & 50 & 20.83 & 165 & 68.75 \\
\hline Breast cancer is contagious. & 95 & 39.58 & 33 & 13.75 & 112 & 46.67 \\
\hline $\begin{array}{l}\text { Smoking \& excessive } \\
\text { alcohol drinking increase the risk of } \\
\text { having this cancer. }\end{array}$ & 24 & 10.00 & 197 & 82.08 & 19 & 7.92 \\
\hline
\end{tabular}

The highest percentages of those who answered correctly of warning signs and symptoms was (15.42) \% which is the puckering or dimpling of breast skin. The lowest percentages of this section were (10.42) \% which refers to a change in the position of the nipple different from the normal is a signs of this cancer.as shown in table 4 
Table(4):Frequency distribution of students' responses about warning symptoms and signs.

\begin{tabular}{|c|c|c|c|c|c|c|}
\hline \multirow{2}{*}{ Questions } & \multicolumn{2}{|l|}{ Yes } & \multicolumn{2}{|l|}{ No } & \multicolumn{2}{|c|}{ Don't know } \\
\hline & $\overline{\mathbf{N}}$ & $\%$ & $\mathbf{N}$ & $\%$ & $\mathbf{N}$ & $\%$ \\
\hline $\begin{array}{l}\text { A change in the position of the nipple } \\
\text { different from the normal is a signs of this } \\
\text { cancer. }\end{array}$ & 25 & 10.42 & 200 & 83.33 & 15 & 6.25 \\
\hline $\begin{array}{l}\text { Pulling of nipple into the breast is one of the signs of } \\
\text { this cancer. }\end{array}$ & 30 & 12.50 & 160 & 66.67 & 50 & 20.83 \\
\hline $\begin{array}{l}\text { Pain in breast or armpit is one of the signsof this } \\
\text { cancer. }\end{array}$ & 26 & 10.83 & 190 & 79.17 & 24 & 10.00 \\
\hline $\begin{array}{l}\text { Puckering or dimpling of breast skin is oneof the } \\
\text { signs of this cancer. }\end{array}$ & 37 & 15.42 & 194 & 80.83 & 9 & 3.75 \\
\hline $\begin{array}{l}\text { Discharge or bleeding from the nipple is a signs of } \\
\text { this cancer. }\end{array}$ & 30 & 12.50 & 202 & 84.177 & 8 & 3.33 \\
\hline $\begin{array}{l}\text { The presence of a lump or thickening in the breast or } \\
\text { the armpit is a signs of this cancer. }\end{array}$ & 35 & 14.58 & 173 & 72.08 & 32 & 13.33 \\
\hline $\begin{array}{l}\text { The presence of rash on the nipple is a signsof this } \\
\text { cancer. }\end{array}$ & 35 & 14.58 & 100 & 41.67 & 105 & 43.75 \\
\hline $\begin{array}{l}\text { Redness of breast skin is a sign of this } \\
\text { cancer. }\end{array}$ & 30 & 12.50 & 182 & 75.83 & 28 & 11.67 \\
\hline $\begin{array}{l}\text { A change in size and shape of breast or } \\
\text { nipple is a sign of this cancer. }\end{array}$ & 33 & 13.75 & 128 & 53.33 & 79 & 32.92 \\
\hline
\end{tabular}

Percentage of students' mentioned that they heard about the breast self - examination was (34.58)\%, whereas low percentage of students' knowledge was the presence of one of the previously mentioned changes requires a consultation of a specialized doctor which had percent of (12.08)\% as shown in table 5: 
Table(5): Frequency distribution of students' responses about breast self - examination.

\begin{tabular}{|c|c|c|c|c|c|c|}
\hline \multirow{2}{*}{ Questions } & \multicolumn{2}{|l|}{ Yes } & \multicolumn{2}{|l|}{ No } & \multicolumn{2}{|c|}{ Don't know } \\
\hline & $\mathbf{N}$ & $\%$ & $\mathbf{N}$ & $\%$ & $\mathbf{N}$ & $\%$ \\
\hline $\begin{array}{l}\text { You heard about the breast self- } \\
\text { examination. }\end{array}$ & 83 & 34.58 & 45 & 18.75 & 112 & 46.66 \\
\hline $\begin{array}{l}\text { The most suitable time for breast screening is } \\
\text { one week after menstrual cycle. }\end{array}$ & 40 & 16.67 & 170 & 70.83 & 30 & 12.50 \\
\hline $\begin{array}{l}\text { Breast self-examination is done at least once in a } \\
\text { month. }\end{array}$ & 33 & 13.75 & 190 & 79.17 & 17 & 7.08 \\
\hline $\begin{array}{l}\text { The presence of one of the } \\
\text { previously mentioned changes requires a } \\
\text { consultation of a specialized doctor. }\end{array}$ & 29 & 12.08 & 192 & 80.00 & 19 & 7.92 \\
\hline $\begin{array}{l}\text { Breast self-examination may be } \\
\text { performed while having a bath. }\end{array}$ & 41 & 17.08 & 195 & 81.25 & 4 & 1.67 \\
\hline $\begin{array}{l}\text { Breast self-examination is } \\
\text { important for an early detection of this cancer } \\
\text { and it is considered one of the essentials to } \\
\text { avoid it. }\end{array}$ & 33 & 13.75 & 195 & 81.25 & 12 & 5.00 \\
\hline
\end{tabular}

All sections percentage scores were less than (50)\% and according to Likert scale the percent score for each section of the questionnaires was poor. The overall percent score of all students' knowledge about breast cancer (risk factors, warning signs and symptoms and breast self - examination) was poor $(48.60 \%)$.as shown in table 6: 
Table (6): Distribution of students' knowledge percentage score by sections.

\begin{tabular}{|l|c|c|}
\hline Section & Percentage Score, \% & Knowledge Description \\
\hline Risk Factors. & 49.54 & poor \\
\hline $\begin{array}{l}\text { Warning Signs and } \\
\text { Symptoms. }\end{array}$ & 47.40 & Poor \\
\hline Breast Self - Examination. & 48.88 & Poor \\
\hline Overall Percent Score. & $\mathbf{4 8 . 6 0}$ & Poor \\
\hline
\end{tabular}

\section{DISCUSSION}

Breast cancer as a multi-etiology disease has created a significant health problem worldwide ${ }^{[13]}$ It is well known that low cancer awareness contributes to delay in presentation of cancer symptoms and subsequent diagnosis leading to unfavorable outcomes (14)

The mean age of the included female students in the current study was $(22.8 \pm 3.4)$ years which is lower than that in Malaysia by Hadi M.A. et al about evaluation of breast cancer awareness among female university students $2010^{[15]}$, a study conducted in the Muscat, Sultanat of Oman by Al Junaibi R.M. et al Knowledge and Awareness of breast cancer among university female students $2011^{[16]}$ and a study conducted by Habib F. et al, Awareness and knowledge of breast cancer among university students in Al-Madina AlMunawara region 2010 which were $(26.7 \pm 1.9,25.65 \pm 5.7$ and $27 \pm 12.1)$ years respectively but it was higher than that of a study conducted by Boulos DNK. et al Awareness of breast cancer among female students at Ain Shams University, Egypt 2014 [18] which was $(19.5 \pm 1.1)$ years.

On the other hand, only $(14.58 \%)$ of the participants had family history of breast cancer which was nearly similar to other studies as Boulos DNK. et al ${ }^{[18]}$, Al Junaibi R.M. et $\mathrm{al}^{[16]}$ and Habib F. et $\mathrm{al}^{[17]}$ which were
(16.1, 13.5 and $14 \%)$ respectively.

The main source of information regarding breast cancer was the internet $(34.17 \%)$ while for the respondents of Habib F. et al ${ }^{[17]}$, it was the television and radio (56.2\%).

Regarding the knowledge responses of risk factors of the disease, highest percentage of correct responses although they were poor (no breast-feeding, early menarche and late menopause, delayed first birth after the age of (30) years $(23.33 \%, 18.78 \%$ and $17.9 \%)$ respectively, while the lower level of awareness were for hereditary, obesity and no physical activity, contraceptive pills and hormone replacement therapy, smoking and excessive alcohol drinking $(16.67 \%, 15 \%, 12 \%, 10 \%)$ respectively. In comparison, the students correct responses percentage were higher with $\mathrm{AL}$ Junaibi R.M. et al ${ }^{[16]}$ for old age, cigarette smoking, high fat diet, no breast feeding, early menarche, contraceptive pills and late menopause which were $(36.7 \%, 33.76 \%, 35 \%$, $38.85 \%, \quad 50.31 \%, \quad 37.58 \%$ and $40.7 \%)$ respectively. In Boulos DNK. et al ${ }^{[18]}$, the students gave different correct responses for (smoking, radiation to chest, genetic factors, age of first full term pregnancy $>30$ years) which were $(66.9 \%, 63.7 \%, 63.7 \%$ and $5.9 \%)$ respectively.

The results of Hadi M.A. et al showed more encouraging results for old age, family history, delay first birth, early menopause and early onset of menstruation, no breast feeding as $(72.5 \%, 91.5 \%, 65 \%, 32 \%$, 
$43.5 \%$ and $66 \%$ ) respectively.

Regarding the awareness of the students of the warning signs and symptoms of breast cancer, the highest correct responses of the students were for puckering or dimpling of breast skin, the presence of lump and the presence of rash around the nipple as $(15.42 \%$, $14.58 \%$ and $14.58 \%$ ) respectively, this was inconsistent with the study of Hadi et al in

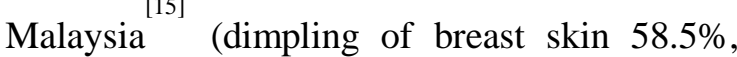
change in the breast shape $81.5 \%$, painless breast lump $72 \%$, lump under armpit $78.5 \%$ and nipple discharge $74.5 \%$ ) also in Boulos DNK. et al ${ }^{[18]}, 81.6 \%$ of students identified breast lump, change in shape or retraction of the nipple and bloody nipple discharge accounting for $(25.6 \%$ and $24.7 \%)$ respectively.

BSE is one of the important steps for identifying breast tumors at early stages ${ }^{[7]}$ it is found that $(34.5 \%)$ of the students in this study heard about BSE and they knew about suitable time and frequency to be performed $(16.67 \%$ and $13.75 \%)$ respectively.

In AL Junaibi R.M. et al ${ }^{[16]}(85.35 \%)$ knew that BSE is helpful in the early detection of breast cancer, (77\%) knew how to perform it and $(72.61 \%)$ knew the frequency of doing it monthly.

In Gwarzo UMD et al Knowledge and practice of breast self-examination among female undergraduate students of Ahmadu Bello University Zaric, Northwestern Nigeria $2009^{[19]}$, although nearly three quarters of the respondents $(87.7 \%)$ had heard about BSE, only $(19 \%)$ of them performing this examination monthly.

Finally, the overall level of awareness about the risk factors, signs and symptoms and BSE were insufficient $(<60 \%)$. This was in agreement with that of Sambanje $\mathrm{MN}$ et al. Breast cancer knowledge and awareness among university students in Angola 2012 ${ }^{[20]}$, the overall mean score for non-medical students was $(9.4 \pm 0.21)$ out of the total possible score of (25), while a study conducted by Early J., et al. about US female college students breast health knowledge, attitude and determinants of screening practices: New implications for health education $2011^{[21]}$ and Sait WA et al and about knowledge of breast cancer among young Saudi females $2010^{(22)}$ students showed gab in women's knowledge of the breast health.

\section{It can be concluded that:}

All sections percentage scores of breast cancer risk factors, warning signs and symptoms and BSE were poor.The overall percent score of all students' knowledge was poor.

\section{REFRENCES}

1-Radi S. Breast Cancer Awareness among Saudi Females in Jeddah, Asian Pacific Journal of Cancer Prevention, 2013, Vol. 14, 4307.

2-WHO, 2008. Breast cancer: Data and statistics.

3-Alwan N; Iraqi Initiative of a Regional Comparative Breast Cancer Research Project in the Middle East. J Cancer Biol Res (2014), 2(1): 1016.

4-Globocan 2008, International Agency for Research on Cancer, Lyon, IARC Press, 2010.

5-WHO, breast cancer: prevention \& control, 2015 [Cited 2015 June 8]; available at: http://www.who.int/cancer/detection/breastcancer/en/. 6-Breast cancer: prevention and control 2015 [Cited 2015 May 4]; available at: http://www.who.int/cancer/detection/breastcancer/en/. 7-Nicole Powell-Dunford, MD; Cancer screening in women, breast cancer; Current diagnosis and treatment in family medicine; Jeannette E. South-

Paul, Samuel C. Matheny; Evelyn L. Lewis, 2011, $3^{\text {rd }}$ edition, 276.

8-American Cancer Society, Cancer facts and figures 2013, American Cancer Society, Inc. No. 500813, 2013.

9-Colditz G.A. and Bohlke K., Priorities for the primary prevention of breast cancer, CA: A Cancer Journal for Clinicians, 2014, Volume 64, Issue 3, p 186- 194.

10-Iraqi national cancer research center, Alwan, N: A.S. historical background, Baghdad University, Iraq. Available at: http://www.bccru.uobaghdad.edu.iq/. 15.

11- Forbes L., Atkins L., Ramirez A., Haste F. and Layburn J., Awareness of breast cancer among women living in inner North East London, BCAM Report 26th July2010 [Cited2015May13]; available http://www.cancerresearchuk.org/prod_consump/grou ps/cr_common/@nr e/@hea/documents/generalcontent/cr_052797.pdf. 12-Norman G. Likert scale levels of measurement and the laws of statistics.

Advances in Health Science Education 2010; 15 (5): 625-632. 
13-Tazhibi M. and Feizi A., Awareness Levels about Breast Cancer Risk Factors, Early Warning Signs, and Screening and Therapeutic Approaches among Iranian Adult Women: A large Population Based Study Using Latent Class Analysis, BioMed Research International (2014), Article ID 306352: 1-9. 14-Nystrom L., How effective the screening for breast cancer? BMJ, 2000. 32,647-649.

15-Hadi M.A., Hassali M.A., Shafie A.A., and Awaisu A. Evaluation of breast cancer awareness among female university students in Malaysia. Pharm Pract (Granada). 2010 Jan-Mar; 8(1): 29-34.

16-Al Junaibi R.M. and Khan S.A., Knowledge and Awareness of breast cancer among university female students in Muscat, Sultanate of Oman- A pilot study. Journal of Applied Pharmaceutical Science 01 (10); 2011: 146-149.

17-Habib F., Salman S., Safwat M., and Shalaly S., Awareness and knowledge of breast cancer among university students in Al-Madina Al-Munawara region. Middle east journal of cancer 2010; 1(4) 159-160.
18-.Boulos DNK., Ghali RR., Awareness of breast cancer among female students at Ain Shams University, Egypt. Global journal of health science. 2014, vol.6, No.1 P:154-161.

19-Gwarzo UMD., Sabitu $\mathrm{K}$ and Idris SH. Knowledge and practice of breast self examination among female undergraduate students of Ahmadu Bello University Zaric, Northwestern Nigeria. Annals of African medicine, 2009, Vol.8., №.1: 55-58.

20-Sambanje MN., Mafuvadze B., Breast cancer knowledge and awareness among university students in Angola. The Pan African Journal, 2012; 11:70.

21-Early J., Armstrong SN., Burke S., Thompson DL. US female college students breast health knowledge, attitude and determinants of screening practices: New implications for health education. JAM Coll Health 2011, 59 (7): 640-670.

22-Sait W.A., Al Amoudi S.M., Tawtai D.A., Abduljabbar H.S., The knowledge of breast cancer among young Saudi females, Saudi med journal 2010, Vol.31(11): 179-181. 